JTTEE5 24:1343

DOI: 10.1007/s11666-015-0359-3

1059-9630/\$19.00 C ASM International

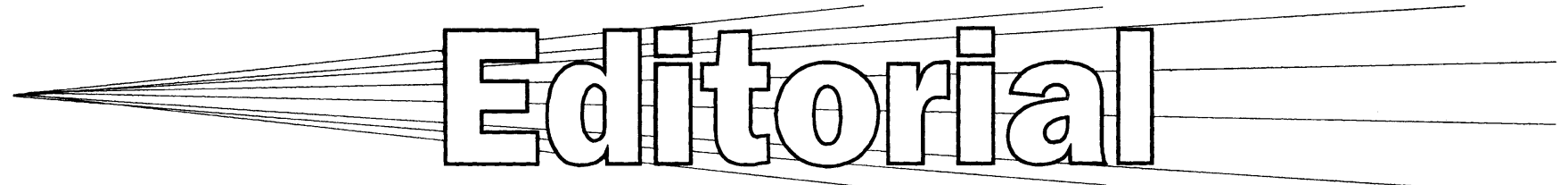

\title{
Journal of Thermal Spray Technology Announces Editorial Transition
}

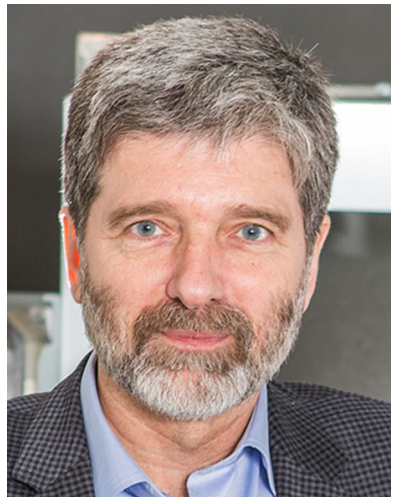

Christian Moreau

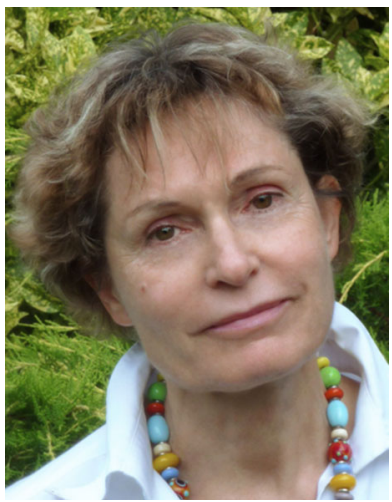

Armelle Vardelle

After 12 years of serving as editor-in-chief of the ASM Journal of Thermal Spray Technology (JTST), Dr. Christian Moreau, FASM, TS HoF, has transferred his responsibilities to Dr. Armelle Vardelle, FASM. Christian became editor of the journal in 2004, and led the journal through an extraordinary period of growth, in which the journal increased from a quarterly to six issues a year in 2007 , then to eight issues a year in 2013.

Christian continued to build on the strong foundation laid by JTST Founding Editor Chris Berndt, FASM, TS HoF. He enlarged the editorial staff to its current complement of five associate editors by identifying individuals who were both well-qualified technically as well as representative of the international readership of the journal. Furthermore, he created the position of "Lead Editor" to focus on special topical and event-related issues of the journal.

In his first editorial as editor-in-chief, Christian wrote, "I want to carry on Chris's vision for the journal. JTST must be the reference journal for all aspects related to thermal spray science and technology, not only for scientists, but also for engineers, students, and sprayers around the word. This will be done by continuously improving the quality of the peer-reviewed papers and making sure that they are of high interest both for industry and the scientific community."

Through the past 12 years, we have seen this vision being fulfilled, with the journal continuing to grow in number of submissions, quality, and articles published. In a very real sense, the journal is what Christian has made it, in terms of scope and quality. Working closely with former JTST Committee chairman Jockel Heberlein and Chris Berndt, Christian brought into reality an annual special double issue of JTST containing invited and expanded papers originating from the International Thermal Spray Conference. Christian led the journal through its transition into the publishing partnership with Springer, which has greatly increased the visibility and accessibility of the journal throughout the world.

A professor at Concordia University (Canada Research Chair, Thermal Spray and Surface Engineering), Christian will continue to offer the journal the benefit of his experience by remaining involved as a member of the JTST Committee.

We would like to take this opportunity to thank Christian publicly for unceasingly providing his insight and dedication as he has skillfully led the journal for the past 12 years. Additionally, Christian has provided for the future success of JTST by identifying a capable and qualified successor. Armelle became Lead Editor of JTST in early 2013 after serving as an associate editor of the journal since 2006. We are delighted that she has accepted the appointment as editor and thank her for accepting this new responsibility. (Please see the related article about Prof. Vardelle in this issue.)

While we will miss our interactions with Christian, we wish him much success in his future endeavors and look forward to his future participation and input as an advisor to the journal. We welcome our new editor, and are confident that she will provide a similarly skillful stewardship for the journal as Christian has done in the past. We wish Armelle satisfaction and success as the new editor.

\author{
Dr. Robert C. Tucker, Jr., FASM, TS HoF \\ Chair \\ Journal of Thermal Spray Technology Committee
}

Mary Anne Fleming

Senior Content Developer, Journals

ASM International 